\title{
Taking Air Passenger Rights Seriously: the Case Against the Exclusivity of the Montreal Convention
}

\author{
Nicolas Bernard \\ Senior lecturer in law, Queen Mary University of London, UK \\ n.bernard@qmul.ac.uk
}

\begin{abstract}
The 1999 Montreal Convention seeks to unify certain rules concerning the liability of air carriers in international air transport. This article highlights the problems that the exclusion of national rules in favour of a unified international legal regime poses from a consumer protection point of view. International trade regulation carries an inherent structural risk of bias in favour of industry rather than consumer interests. Drawing inspiration from international human rights law, the alternative of an inspired approach based on subsidiarity is put forward, which, instead of seeking rigid uniformity at international level, allows for the recognition of a complementary role for international, regional and national levels in protecting consumers. The feasibility of adopting such a perspective in interpreting the Montreal Convention is also considered.
\end{abstract}

\section{Keywords}

International air transport - Montreal Convention - air carrier liability - consumer protection subsidarity 


\section{Introduction}

"[D]emonstrably incorrect", "fundamentally flawed", ${ }^{2}$ not just wrong but "WRONG", ${ }^{3}$ motivated by a "political obsession for consumer rights", "Brussels's triumphant assertion of power and authority sacrific[ing] global uniformity in the rule of law", ${ }^{5}$ a Court bent on rewriting legislation and raising "serious concerns about the rule of law": 6 it would be a major understatement to say that the academic and practising lawyers specialising in aviation law have not received the rulings of the European Court of Justice in the IATA ${ }^{7}$ and in the Sturgeon ${ }^{8}$ and Nelson ${ }^{9}$ cases with great enthusiasm. Robust criticism of judicial pronouncements is par for the course in academic writing. Such degree of vitriol is, however, less common. There seems to be something visceral at stake here going beyond genteel senior common room discussions of the respective merits of various interpretations of the law.

If those judgments touched such a raw nerve, it might be because they are perceived to be challenging one of the sacred cows of international air transport law, namely the exclusivity of the 1999 Montreal Convention. ${ }^{10}$ The Montreal Convention, like its predecessor, the Warsaw Convention, ${ }^{11}$ seeks to harmonise the rules relating to the liability of air carriers for damage or delay in the carriage by air of passengers, baggage and cargo. To that end, it contains a clause ${ }^{12}$ which preempts the application of national or other local rules ${ }^{13}$ that might otherwise have been applicable in the absence of the Convention. This pre-emptive effect is regarded by aviation lawyers as a fundamental aspect of the legal regime established by the Montreal Convention ${ }^{14}$ and reflected in the title of the Convention as a Convention for the unification of certain rules for international carriage by air. Challenging that pre-emptive effect therefore goes to the root of what the Montreal Convention is about and is, in their eyes, anathema.

\footnotetext{
1 John Balfour, "Further comment on Case C-344/04, The Queen ex parte International Air Transport Association, European Low Fares Airline Association v. Department for Transport, Judgment of the Court (Grand Chamber) of 10 January 2006", 44 Common Market Law Review (2007), p. 560.

2 John Balfour, 'Luxembourg v Montreal: Time for the Hague to Intervene', in M. Bobek and J. Prassl (eds.), Air Passenger Rights: Ten Years On (2016), p. 73.

${ }^{3}$ George N. Tompkins Jr, "Are the Objectives of the 1999 Montreal Convention in Danger of Failure?", 39 Air and Space Law (2014) p. 212.

${ }^{4}$ Ibid.

${ }^{5}$ Paul Stephen Dempsey and Svante O Johansson, "Montreal v. Brussels: The Conflict of Laws on the Issue of Delay in International Air Carriage", 35 Air and Space Law (2010) p. 224.

${ }^{6}$ John Balfour, "Airline liability for Delays: The Court of Justice of the EU Rewrites EC Regulation 261/2004", 35 Air and Space Law (2010) p. 75.

${ }^{7}$ Case C-344/04, IATA and ELFAA, EU:C:2006:10.

8 Joined cases C-402/07 and C-432/07, Sturgeon and Böck, EU:C:2009:716.

9 Joined Cases C-581/10 and C-629/10, Nelson and Others, EU:C:2012:657.

${ }^{10}$ Convention for the Unification of Certain Rules for International Carriage by Air (adopted 28 May 1999, entered into force 4 November 2003) 2242 UNTS 309 (Montreal Convention).

${ }^{11}$ Convention for the Unification of Certain Rules Relating to International Carriage by Air (adopted 12 October 1929, entered into force 13 February 1933) 137 LNTS 11 (Warsaw Convention).

12 Article 29. The corresponding provision in the Warsaw Convention was Article 24.

${ }^{13}$ Such as, for instance, legal provisions adopted by regional organisations like the European Union.

${ }^{14}$ See, for instance, Tompkins, supra note 3, p. 204; Dempsey and Johansson, supra note 5, p. 209.
} 
It is not the primary purpose of this article to discuss whether the Court of Justice was right or wrong in the cases mentioned above..$^{15}$ It may well be that certain aspects of the judgments could be questionable from a purely doctrinal point of view, although one should mention that the reaction outside the aviation legal community, and in particular among EU lawyers, ${ }^{16}$ was generally more subdued and nuanced or even favourable. ${ }^{17} \mathrm{My}$ main concern in this contribution is of a more normative nature and relates to the deleterious consequences on consumer protection of the exclusivity of the Montreal Convention.

On that terrain, the case in favour of the Montreal Convention is rather more problematic to make. Historically, Montreal's predecessor, the Warsaw Convention, was undoubtedly designed to protect airlines from passenger lawsuits. Rather than a consumer protection instrument, it was rather the reverse. Even now, however, the exclusivity rule of the Montreal Convention still functions as a device to protect airlines from liability to consumers. One might be tempted to argue that this is merely contingent and reflects the current preferences of states that are parties to the Convention as to how to balance consumer interests and industry interests in the field of international air transport. This is tautologically true, in the sense that international treaties are ratified by states and the act of ratification, in so far as it entails consent of the state to be bound, ipso facto reflects the current preferences of the state concerned at the time of ratification. This, however, is a rather formal view of international treaty-making. Looking beyond the formal level, if, as will be argued below, international regulation of the airline industry is structurally biased in favour of airline interests and if we are serious about protection of international passengers, we cannot be satisfied with a system of regulation which purports to exclude other levels of regulation. What we could instead do is to approach the protection of consumer rights at international level in the same way as we approach the protection of human rights at international level, namely recognising that there is a role for international protection but that different levels of regulations (international, regional, national) have complementary roles to play in providing a coherent system of protection of consumer interests.

This article will be structured as follows: the role of the exclusivity rule in the Warsaw and Montreal Convention in protecting airlines will first be examined (section B). The extent to which industry regulation at international level tends to inherently favour industry interests will then be discussed (section C). Finally the case for adopting a human rights-inspired, subsidiarity-based approach to passenger rights protection will be made (section D).

\footnotetext{
${ }^{15}$ Some aspects of the ECJ caselaw on air passenger rights will however be touched upon below.

${ }^{16}$ See, in particular, Kieran St Clair Bradley, "Case C-344/04, The Queen ex parte International Air Transport Association, European Low Fares Airline Association v. Department for Transport, Judgment of the Court (Grand Chamber) of 10 January 2006", 43 Common Market Law Review (2006) pp. 1101-1124; Koen Lenaerts and José A. Gutiérrez-Fons, "The constitutional allocation of powers and general principles of EU law", 47 Common Market Law Review (2010) pp. 1636-1637; Jules Stuyck, "Indemnisation pour les passagers de vols retardés en Europe", 7 La Semaine Juridique, Edition Générale (2010) pp. 359-363; Jeremias Prassl, "The European Union and the Montreal Convention: A New Analytical Framework", 12 Issues in Aviation Law and Policy (2013) pp. 381-412.

${ }^{17}$ To some extent, the contrasting reactions of EU and aviation lawyers may be a reflection of different disciplinary "mind-sets." See David McClean, "EU Law and the Montreal Convention of 1999", in Bobek and Prassl (eds.), supra note 2, p. 57. McClean contrasts what he calls an "internationalist" perspective to a "European" one but adds that the CJEU may represent a third distinct "mind-set". He does not make clear, however, how the "European" and "CJEU" mind-sets might in his view differ.
} 


\section{Protecting airlines rather than consumers}

Historically, it is clear that the liability regime established by the Warsaw Convention was deliberately set up to protect the airline industry. The Convention's travaux préparatoires indicate that there was concern that "investors and insurance companies feared the uncertainty in the law governing international flights" as the "potential liability for a single accident was staggering." ${ }^{18}$ Protecting airlines liability rules that might exist in national law was thus seen as crucial, hence the need for an exclusivity clause to block the operation of ordinary domestic rules on civil liability. ${ }^{19}$ In return, a token gesture was made in the direction of passengers in the form of a reversal of the burden of proof ${ }^{20}$ and the exclusion of any further contractual lowering or exclusion of liability below the level specified in the Convention. ${ }^{21}$ Even in 1929, this could hardly be seen as a genuine quid pro quo given the huge disproportion between the advantages to air carriers and those to passengers but this became even more so over time. Inflation accentuated the negligible significance of the issue of further contractual limitations on liability on the already very low ceiling imposed by the Convention. As regards the burden of proof, many countries applied or would later apply to air accidents legal devices or doctrines, the effect of which was to more or less reverse the burden of proof, such as, for instance, the semi-strict liability system of responsabilité du fait des choses in French law or the concept of res ipsa loquitur in some common law jurisdictions (not least the USA). ${ }^{22}$ The supposed added value from a consumer perspective of the Warsaw Convention was thus minimal whereas the downside was considerable.

The Montreal Convention, however, purports to engage with consumer protection more seriously than its predecessor. Its preamble explicitly refers to the "importance of ensuring protection of the interests of consumers in international carriage by air." With the adoption of a strict liability regime up to 100,000 Special Drawing Rights in case of death or injury to passengers, the most outrageously anachronistic restrictions in the Warsaw regime on airline liability in case of accident have been removed. Yet, the persistence of the aim of a unified regime of carrier liability at international level and the continued existence of an exclusivity clause in Article 29 of the Montreal allows us to doubt the depth of commitment of the Montreal Convention to consumer protection. ${ }^{23}$ It is clear that this clause still acts as a bar to potential liability claims by passengers based on national law, as will be seen below.

What is particularly remarkable is that this exclusivity operates not just against the application of general rules on contractual or tortious liability, which was arguably what the exclusivity rule

\footnotetext{
${ }^{18}$ Minutes of the Second International Conference on Private Aeronautical Law, October 4-12 1929 Warsaw, translated by Robert C. Horner and Didier Legrez (1975) pp. 18-23.

${ }^{19}$ Article 24 provides that, in cases falling within the scope of (Articles 17 to 19 of) the Convention, "any action for damages, however founded, can only be brought subject to the conditions and limits set out in this Convention."

${ }^{20}$ Articles 17 and 20.

${ }^{21}$ Article 23.

${ }^{22}$ With respect to the US, see Andreas F. Lowenfeld and Allan I. Mendelsohn, "The United States and the Warsaw Convention", 80 Harvard Law Review (1967) pp. 519-522.

${ }^{23}$ Article 29 of the Montreal Convention provides that "[i]n the carriage of passengers, baggage and cargo, any action for damages, however founded, whether under this Convention or in contract or in tort or otherwise, can only be brought subject to the conditions and such limits of liability as are set out in this Convention." On the limited significance of the change of wording compared to Article 24 of the Warsaw Convention, see Marc McDonald, "The Montreal Convention and the Preemption of Air Passenger Harm Claims", XLIV The Irish Jurist (2010) pp. 218-219.
} 
primarily targeted, but also any kind of liability or carriers towards passengers of whatever source and for whatever purpose, even if founded on statutory duties or even fundamental rights protection principles or legislation. In addition to this, the exclusivity rule has the potential to prevent the emergence of new legislation to protect air passenger rights in case of travel disruption.

\subsection{Protecting airlines from tortious or contractual liability towards passengers}

The exclusionary effect of the exclusivity rule under the Warsaw and Montreal Convention and the creation of zones of legal immunity in which airlines are protected from liability to passengers is well illustrated by the two leading cases on that rule in the US and the UK.

In Tseng, ${ }^{24}$ decided by the US Supreme Court under the Warsaw Convention, the plaintiff claimed that she had suffered mental injury as a result of an invasive body search carried out by airline security personnel before boarding a flight from New York to Tel Aviv. In Sidhu, ${ }^{25}$ decided by the UK House of Lords also under the Warsaw Convention, ${ }^{26}$ a British Airways flight from London to Kuala Lumpur made a refueling stop in Kuwait five hours after Iraqi troops invaded Kuwait at the beginning of the Gulf war. The aircraft was seized and passengers detained by Iraqi forces for about one month, during which they suffered psychological harm as well as, in one case, physical injuries. The passengers argued that the airline knew or ought to have known that there was a severe risk of passengers being put in danger if the aircraft landed in Kuwait and therefore attributed their injuries to the negligence of the airline. Under the Warsaw Convention and Montreal Conventions, the carrier is liable for damage in case of death and bodily injuries to the passenger resulting from an "accident" which "took place on board the aircraft or in the course of any of the operations of embarking or disembarking." 27 In both cases, the parties agreed that there was no "accident" within the meaning of the Warsaw Convention and that, therefore, a claim under the Convention would fail. ${ }^{28}$ The question before both courts was therefore whether the exclusivity rule in the Convention precluded reliance on another cause of action founded in national law, to which both courts answered affirmatively.

Following the interpretation adopted by the US Supreme Court in Tseng and by the UK House of Lords in Sidhu, the effect of the exclusivity of the Montreal Convention is to create bubbles of legal immunity, in which the law is incapable of reaching actions by airlines that cause harm to passengers: No liability can arise under the Montreal Convention because the harm caused to passengers does not result from an "accident" or because the harm does not consist of death or bodily injury. Neither can local law apply because, in the carriage of passenger by air, the exclusivity clause in Article 29 of the Montreal Convention pre-empts any action based on local law, however founded.

Admittedly, it is debatable whether either case fell at all within the scope of the Convention. ${ }^{29}$ In Tseng, the search was carried out before check-in, which is neither "on board the aircraft" nor,

\footnotetext{
${ }^{24}$ El Al Israel Airlines, Ltd. v. Tsui Yuan Tseng, 525 U.S. 155 (1999).

${ }^{25}$ Sidhu and others $v$ British Airways [1997] A.C. 430.

${ }^{26}$ The slight difference of wording under the Montreal Convention (see supra note 23) would not result in a different outcome.

${ }^{27}$ Article 17 of the Warsaw Convention and 17(1) of the Montreal Convention.

${ }^{28}$ In any event, the claim would in all likelihood also have failed on the ground that the Convention did not cover mental injuries which were not associated to a bodily injury.

${ }^{29}$ See McDonald, supra note 23, pp. 216-217.
} 
arguably, "in the course of any of the operations of embarking or disembarking." In Sidhu, the detention took place while the individuals were in the terminal in Kuwait, which is also neither on board the aircraft nor during embarkation or disembarkation operations. However, the Court had been asked by the parties in both cases to proceed on the basis that it was accepted that the case fell within the scope of the Convention. In any event, this is not crucial for our present purposes: one can easily imagine slight tweaks to the facts, such as the search in Tseng being carried out at the gate during the embarkation process or the troops in Sidhu detaining passengers on board the aircraft, thereby bringing the situation much more clearly within the scope of the Convention. The point here is the arbitrariness of leaving those situations outwith the realm where the carrier ought to be responsible for harm resulting from its actions.

Tseng and Sidhu both concerned the potential tortious liability of the air carrier. However, the same issue could arise in a contractual context. Thus, an airline could completely fail to deliver the onboard service that it has contractually agreed to provide the passenger during flight and yet not be liable at all to the passenger on account of this failure: to the extent that the failure to deliver the service does not constitute an "accident" and that, moreover, the passenger does not suffer a bodily injury as a consequence of that failure, no liability can arise under the Montreal Convention. And since the Montreal Convention pre-empts contractual actions as well as tortious ones, no action under national law is possible either. ${ }^{30}$

\subsection{Protecting airlines from statutory duties towards passengers}

As noted above, it is not just ordinary contract and tort claims that are potentially pre-empted by the exclusivity rule in the Montreal Convention. Any form of liability of air carriers towards passengers, even if it derives from statutory duties reflecting public law and constitutional concerns such as issues of protection of fundamental rights, is potentially pre-empted by the Montreal Convention.

The potential impact of the exclusivity rule on fundamental rights can be illustrated by reference to two decided cases, in Canada and the UK respectively.

Thibodea ${ }^{31}$ concerned the interaction between the Montreal Convention and the linguistic regime in Canada resulting from the Official Languages Act (OLA). ${ }^{32}$ The OLA establishes a right for members of the public to communicate with, and obtain available services from, federal authorities in either of two official languages of Canada, viz. English or French. The OLA has been described by the Supreme Court of Canada as belonging to "that privileged category of quasi-constitutional legislation which reflects 'certain basic goals of our society' and must be so interpreted 'as to advance the broad policy considerations underlying it'" ${ }^{33}$ It is therefore clear that the rights conferred in the OLA have quasi-constitutional status in Canada. The Thibodeaus had flown on a number of occasions on Air Canada between Canada and the US and complained that no French-speaking flight attendant was available and/or that flight announcements had been made exclusively in English. It was

\footnotetext{
${ }^{30}$ See Knowlton v American Airlines 2007 US dist lexis 6882. On this case, see George N. Tompkins, "The Case of the Missing 3 Dollar Breakfast and the Pre-emptive Effect of the Montreal Convention", 32 Air and Space Law (2007) pp. 229-231.

${ }^{31}$ Thibodeau v Air Canada 2014 SCC 67.

${ }^{32}$ R.S.C. 1985, c. 31 (4th Supp.) (Can.).

${ }^{33}$ Lavigne v. Canada (Office of the Commissioner of Official Languages), 2002 SCC 53, para. 23.
} 
accepted that this constituted a breach of the Thibodeaus' language rights under the OLA. ${ }^{34}$ The question that the Supreme Court of Canada had to answer was whether the Thibodeaus' claim for damages under the OLA was pre-empted by the exclusivity rule in the Montreal Convention. Among other arguments, the Thibodeaus considered that the Montreal Convention did not contemplate claims based on public law and of a quasi-constitutional nature so that the exclusivity rule in the Convention should not apply to their claim. While that argument found some support in the Court, the majority nonetheless dismissed it and considered that the Montreal Convention precluded any claim to damages other than provided for in the Convention by a passenger against a carrier in relation to events on board on aircraft or during embarkation or disembarkation.

The Stott case, ${ }^{35}$ decided by the UK Supreme Court, concerned a serious failure by an airline to make sufficient arrangement to provide for the needs of a disabled passenger, in breach of EU legislation on the rights of disabled passengers and its UK implementing measures. ${ }^{36}$ This resulted in chaotic scenes as Mr Stott, who was paralysed from the shoulders down, fell on the floor as his wheelchair overturned on entering the aircraft with the crew unable to deal with the situation. His wife also had repeatedly to kneel or crouch in the aisle to attend to her husband's personal needs. The treatment of $\mathrm{Mr}$ Stott was so disgraceful as to lead Lady Hale in the judgment to conjecture that there was a good case to make that the treatment would have amounted to inhuman or degrading treatment within the meaning of Article 3 of the ECHR has it been meted out by the State rather than a private party. In a similar argument to that of the Thibodeaus regarding the scope of the exclusivity rule, $\mathrm{Mr}$ Stott sought to argue that the Montreal Convention did not seek to regulate the rights of access to air travel for disabled people and that, therefore, a claim under EU or UK legislation on the rights of disabled passengers would not be pre-empted by the Convention. Like the Canadian Supreme Court, however, its UK counterpart considered that the Convention would pre-empt any claim by a passenger towards an airline regarding damage caused on board, regardless of the basis for the claim.

In the US, one could also mention the King case, ${ }^{37}$ concerning a denial of boarding allegedly based on racial discrimination, as another example of conflict between fundamental rights and the Warsaw Convention pre-empted in favour of the Convention.

Thus the protective envelope shielding airlines from legal duties towards their passengers is not limited to ordinary contract and tort matters but can result in passengers being stripped of the fundamental rights they would normally be able to invoke in any other context than that of international air transport.

\footnotetext{
${ }^{34}$ While Air Canada is a private company, it used to be a Crown corporation and, as such, a federal institution for the purposes of the OLA. At the time of privatization, it was decided that the OLA should remain applicable to it notwithstanding the privatization.

${ }^{35}$ Stott v Thomas Cook Tour Operators Ltd [2014] UKSC 15.

${ }^{36}$ The relevant provisions are Regulation (EC) No 1107/2006 of the European Parliament and the Council concerning the rights of disabled persons and persons with reduced mobility when travelling by air [2006] OJ L204/1 and the UK Civil Aviation (Access to Air Travel for Disabled Persons and Persons with Reduced Mobility) Regulations 2007 (SI 2007/1895).

${ }^{37}$ King v American Airlines 284 F 3d 352.
} 


\subsection{Protecting airlines from new legislation on air passenger rights}

The compatibility of the EU regime for protection of air passenger rights in case of flight delays and cancellations enshrined in Regulation $261 / 2004^{38}$ was one of the issues at stake in the European Court of Justice rulings mentioned in the introduction to this article. ${ }^{39}$

As interpreted by the Court of Justice, ${ }^{40}$ Regulation 261/2004 requires carriers, in case of flight cancellations or delays exceeding a duration specified in the Regulation, to provide assistance to passengers consisting of, inter alia, meals and refreshments as well as overnight accommodation to the extent required by the delay ${ }^{41}$ as well as a fixed amount of compensation as determined by Article 7 of the Regulation. ${ }^{42}$ To the extent that Article 19 of the Montreal Convention provides for the liability of the carrier in case of delay, the exclusivity rule in Article 29 of the Convention would seem to preempt any competing system of liability of the carrier in case of delay at national or supranational level.

In the IATA case, ${ }^{43}$ the Court of Justice brushed aside the argument that the liability of airlines to passengers in cases of delay was expressly covered by Article 19 of the Convention and therefore fell within the scope of the exclusivity clause in Article 29 by distinguishing between two kinds of damages in case of delay: damage which is identical or almost identical for all passengers, redress for which may be standardized and individual damage which is peculiar to each individual traveler and needs to be assessed individually on a case-by-case basis. According to the Court, the Montreal Convention is only concerned with the latter and not the former. Therefore, Articles 19 and 29 of the Montreal Convention do not preclude rules such as those in Regulation 261/2004 which concern redress for the former and not the latter.

Most aviation lawyers have been very critical of this distinction between two kinds of damages, regarding it as wholly artificial and without justification. ${ }^{44}$ They have a point. The Montreal Convention does not distinguish between different kinds of damages. If an action concerns damages occasioned by a delay to the carriage by air of passengers, it seems to fall squarely within the scope of Article 19 of the Convention, whether those damages are the same for everybody or particular to an individual. The two types of damages distinction thus seems like a fig-leaf used by the Court to avoid the exclusivity of the Convention.

Yet, while the phrasing in terms of different kinds of damages was perhaps not particularly helpful, it does not follow from this that it is obvious that the Convention necessarily excludes the creation of a statutory scheme of assistance to passengers. Another way to look at it is that Regulation 261/2004

\footnotetext{
${ }^{38}$ Regulation (EC) No 261/2004 of the European Parliament and of the Council of 11 February 2004 establishing common rules on compensation and assistance to passengers in the event of denied boarding and of cancellation or long delay of flights, and repealing Regulation (EEC) No 295/91, [2004] OJ L46/1.

${ }^{39}$ See supra notes 7,8 and 9 .

${ }^{40}$ In case of delay, as distinct from compensation, the wording of the Regulation suggested that the carrier had to provide assistance in the form of the "right to care" under Article 9 but not the "right to compensation" under Article 7. The Court of Justice, however, read into the Regulation a right to compensation in case of delays in the Sturgeon case, supra note 8.

${ }^{41}$ This is the "right to care" provided for in Article 9 of the Regulation.

${ }^{42}$ The amount varies from $€ 125$ to $€ 600$ depending on the length of the flight and of the delay on arrival at destination compared to the original schedule.

${ }^{43} \mathrm{n} 7$.

${ }^{44}$ See, for instance, Balfour, supra note 1, pp. 558-560.
} 
is not concerned at all with damages. The idea of damages is linked to the idea of making good for a loss or injury suffered by a person as the consequence of an act or event. This is arguably not what Regulation 261/2004 is concerned with. The Regulation is not about redress for loss. It is about providing assistance: a delay has occurred. We do not ask ourselves whether an individual has suffered a loss as a result of that delay and how we could make good for that loss. We are faced with a practical situation: an individual needs assistance (food, accommodation, etc...) and the airline is tasked with a duty to provide that assistance. Seen that way, there is no necessary conflict between a Convention that exclude competing national rules on damages to passengers in cases of delay and national or EU rules concerned with establishing a scheme of assistance to passengers, independently of any damages that those passengers may have suffered or not. Nor should we see any action in damages for breach of an airline's obligation under the Regulation as covered by Article 29 either: such damages are damages for a breach of statutory obligations on the airline which are separate and distinct from any action in damages for the delay itself and, therefore, outwith the scope of Article 29.

One might therefore take the view that it is possible to design a scheme of assistance to passengers which is compatible with the Montreal Convention and that Regulation 261/2004 establishes such a scheme. For present purposes, however, what matters is that it is clear that there is at least a tension between an expansive interpretation of the exclusivity rule in the Montreal Convention and the development of consumer rights in air passenger transport and that, therefore, Article 29 of the Convention has the potential to act as a protector of airlines rather than passengers in this context.

\section{Structural imbalance in the protection of consumer and industry interests in international airline regulation}

In Stott, Lady Hale expressed the view that the absence of legal redress to passengers who had been so appallingly treated by an airline was disgraceful but she felt that the only way forward was for the Convention to be amended. The exposure of such a "grave injustice" in this case, she concluded, should lead the international community to turn its attention to the issue. ${ }^{45}$

The precedent of the Warsaw Convention, however, does not bode well in terms of the ability of the international community to mobilize so as to eradicate "grave injustices" in air carrier liability. The shocking character of the pitiful limits on liability in the original Warsaw Convention had already been denounced as "anachronistic and unfair" ${ }^{46}$ in the 1950s and 1960s. Yet, it took almost another half a century for agreement to be reached for these provisions to be replaced by less inappropriate ones in the Montreal Convention.

Placing one's faith in enlightenment on consumer issues at the international level may be somewhat imprudent when, both in terms of process and in terms of substance, international air transport regulation suffers from structural biases in favour of the industry and to the detriment of consumers. In terms of process, the problem is one of imbalance in terms of voice: international regulatory processes provide multiple avenues for airlines to influence the process and let their voice be heard without a comparable level of representation for consumers. In terms of substance,

\footnotetext{
45 Stott, paras. 67-70..

46 "Protecting Airline Passengers", New York Times (23 October 1965), p. 30. On the already outdated nature of the Warsaw Convention even then, see also Lee S. Kreindler, "The Denunciation of the Warsaw Convention", 31 Journal of Air Law and Commerce (1965) pp. 291-302.
} 
international protection of consumer rights tends to gravitate towards the lowest common denominator.

\subsection{The influence of airlines in international air transport regulatory processes}

Imbalance in representation of business versus consumer interests is a well-known issue for scholars working in consumer law or regulation studies. Part of the problem stems from the disproportionate cost of organising diffuse and fragmented interests such as consumer interests compared to the more concentrated interest of business, as shown in Olson's seminal work on collective action over 50 years ago. ${ }^{47}$ If a large number of persons stand to each make a relatively small gain from a change of policy and a small number of persons on the other side stand to each make a large loss from such a change, the latter group will not only find it much easier to collectively organise themselves due to their smaller number but each person in the group will have a much stronger incentive to do so than members of the former group. ${ }^{48}$ This is true even if the total gains for the former, more diffuse group are very considerably larger than the total losses from the latter group so that the polity as a whole would benefit from the policy change. Thus a small group of manufacturers is more likely to organise themselves to lobby a policy-maker ${ }^{49}$ over a given issue than a large group of consumers are likely to do. Secondly, and to some extent as a consequence of this, concentrated interests are likely to have permanent resources allocated to such lobbying activity, making the marginal cost of further lobbying substantially lower. Thirdly, business is also more likely to have resources at its disposal, such as information and expertise, which may be useful or even necessary to policy-makers and regulators. Even if this need not necessarily lead to full-blown regulatory capture, ${ }^{50}$ it is likely at the very least to afford business access to and the ear of policy-makers, and therefore opportunity to influence policy. Fourthly, in so far as economic activity and investments decisions are in the hands of business and government policy is dependent on those decisions to attain its objectives, this gives business a structurally privileged position in the political decision-making process. ${ }^{51}$

The literature, however, is far from unanimous in finding business dominance in regulatory processes and outcomes. In the US, Bailey has, for instance, found that there was a tendency to under-estimate the 'quiet influence' of diffuse interests, such as those of consumer or workers, over American trade policy. ${ }^{52}$ Trumbull has similarly provided multiple examples on both sides of the Atlantic of victories of consumer interests over business interests. ${ }^{53}$ If the claim is that business does not always win all battles and that the public interest will sometimes trump private commercial interests, then it is undoubtedly true. But this would be setting the bar rather low. If anything, one would expect that, in democratic processes, the public interest and collective interest should take priority over private commercial interests as a matter of course. There are also methodological difficulties in quantifying business influence. Regulatory choices are not necessarily black and white.

\footnotetext{
${ }^{47}$ Mancur Olson, The Logic of Collective Action: Public Goods and the Theory of Groups (1965).

48 One should also add that large groups are also more prone to give rise to free-rider problems.

${ }^{49}$ Or indeed lobby individually for very large businesses.

${ }^{50}$ One need not, therefore, necessarily conclude that 'as a rule, regulation is acquired by industry and is designed and operated primarily for its benefit.' (George J. Stigler, "The Theory of Regulation", 2 The Bell Journal of Economics and Management Science (1971) p. 3).

${ }^{51}$ Charles Lindblom has been particularly associated with this view: Charles E. Lindblom, Politics and Markets: The world's political-economic systems, (1977).

52 Michael Bailey, "Quiet Influence: The Representation of Diffuse Interests on Trade Policy", 26 Legislative

Studies Quarterly (2001) pp. 45-80.

${ }^{53}$ Gunnar Trumbull, Strength in Numbers: The Political Power of Weak Interests (2012).
} 
Those entrusted with regulatory design may have multiple choices along a spectrum of possible solutions which may be more or less favourable to business. The fact that the one which is most favourable to the industry has not been adopted does not per se indicate a lack of influence of business if the least favourable one has also not been adopted.

Looking at it with lawyer's eyes, and therefore with a greater focus on legitimacy considerations rather than the raw political fact of influence in itself, it is also somewhat problematic to equate influence exercised through open debate in the public sphere and influence exercised in private discussions. From this perspective, it is worth pointing out that diffuse interests tend to rely on different mechanisms and different institutional points of entry to make their voice heard in decision-making processes. Diffuse interests tend to be more reliant on outside lobbying so as to put electoral pressure on elected representatives through public opinion. ${ }^{54}$ They therefore tend to be more successful in relation to issues which are high profile and which involve input from legislatures. ${ }^{55}$ By contrast, business interests tend to be more reliant on inside lobbying and 'quiet words ${ }^{\prime 56}$ discreetly whispered to the ears of decision-makers in executive or administrative institutions. $^{57}$

A consequence of this of relevance to our particular context is that the environment of international treaty negotiations, dominated as it is by the executive with a limited scope for legislatures to influence outcomes, tends to exacerbate the difficulties encountered by diffuse interests such as consumer interests to make their voice heard. Admittedly, international NGOs and social movements representing diffuse interests have in the last couple of decades prised open to some extent the doors of the international treaty-making citade $\left.\right|^{58}$ and opportunity structures for diffuse interests to influence policy outcomes can exist in international negotiations. ${ }^{59}$ International air transport regulation, however, has to date remained much closer to Keohane and Nye's 'club model ${ }^{\prime 60}$ that used to characterise international intergovernmental negotiations on trade policy and regulation, that is to say a model in which like-minded sectorally specialised officials negotiate in a closed manner among themselves, presenting other constituencies, such as domestic legislatures and the wider public, with the fait accompli of an international agreement that can only be accepted or rejected as a whole. What is more, the historic links between airlines and national governments

\footnotetext{
${ }^{54}$ Andreas Dür and Gemma Mateo, "Gaining access or going public - Interest group strategies in five European countries", 52 European Journal of Political Research (2013) pp. 660-686.

${ }^{55}$ Andreas Dür, Patrick Bernhagen and David Marshall, "Interest Group Success in the European Union: When (and Why) Does Business Lose?", 48 Comparative Political Studies (2015) p. 959. On the importance of electoral incentives and salience to spur action in favour of diffuse interests, see also, from a US perspective, Susan M. Miller, Christopher Witko and Neal D. Woods, "How the Unorganized Mass Public (Sometimes) Gets Represented in Regulatory Politics", 71 Political Research Quarterly (2018) pp. 88-101.

${ }^{56}$ Tamasin Cave and Andy Rowell, A quiet Word: Lobbying, Crony Capitalism and Broken Politics in Britain (2014).

57 Jeremy J Richardson and A G Jordan, Governing under pressure: The policy process in a post-parliamentary democracy (1979).

${ }^{58}$ See, for instance, the role of NGOs in the TTIP and CETA negotiations: Dirk De Bièvre "The Paradox of Weakness in European Trade Policy: Contestation and Resilience in CETA and TTIP Negotiations", 53:3 The International Spectator (2018) pp. 70-85.

59 See Christian Downie, “International Negotiations", in Peter Drahos (ed.), Regulatory Theory - Foundations and Applications (2017) pp. 331-334.

${ }^{60}$ Robert O Keohane and Joseph S Nye Jr, "The Club Model of Multilateral Cooperation and Problems of Democratic Legitimacy", in R. B. Porter, P. Sauvé, A. Subramanian and A Beviglia Zampetti (eds.), Efficiency, Equity, and Legitimacy: The Multilateral Trading System at the Millennium (2001) pp. 280-323.
} 
as well as the structure of the airline industry, notably the existence of a strong organisation representing airline interests, have further accentuated the marginalisation of the consumer voice compared to that of the industry.

\subsubsection{Airlines and governments}

Historically, airlines have entertained extremely close relationships with governments. For a large part of the $20^{\text {th }}$ century, air carriers were mostly state-owned. That states should have a strong interest in transport industries is not in itself surprising. The existence of a functioning transport infrastructure is usually regarded as essential to the proper functioning of the economy and therefore an important element of industrial policy. The interests of states in air transport went, however, beyond that and regarded the provision of air transport services as a manifestation of sovereignty, ${ }^{61}$ giving rise to a culture of "aero-nationalism. ${ }^{\text {" }}{ }^{62}$ This resulted in the development of a highly regulated environment at the international level under the 1944 Chicago Convention on International Civil Aviation, ${ }^{63}$ in which each state ensured that the interests of its own flag carrier were protected in international air transport. ${ }^{64}$ National aviation policy was heavily focused on supporting the flag carrier. ${ }^{65}$

The late 1980s, however, saw a marked shift towards deregulation and privatisation of the airline industry. ${ }^{66}$ This has undoubtedly had a significant impact on the relationship between airlines and governments, particularly in the EU where governments have lost much of their ability to financially support their own airlines. On the other hand, it is clear that relationships between airlines and governments have remained close. As Kassim notes in the EU context, national governments "are no longer the gate keepers for national interests" and airlines lobby EU institutions directly, they nevertheless also look to their government to pursue their interests in Council negotiations. ${ }^{67}$ Van den Polder's account of the lobbying efforts of KLM around the time of airline liberalisation in the EU in the late 1980s and early 1990s gives a good flavour of the extent to which national governments can act as the transmission belt of airline interests in international negotiations. ${ }^{68}$ Even though KLM was one of the rare flag carriers in the EU not to be majority-owned by its Member State, it is clear

\footnotetext{
${ }^{61}$ Anthony Sampson, Empires of the Sky: The Politics, Contests and Cartels of World Airlines (1984) pp. 115120.

62 Jan Walulik, Progressive Commercialization of Airline Governance Culture (2017) pp. 9-17.

${ }^{63}$ Convention on International Civil Aviation (adopted 7 December 1944, entered into force 14 April 1947) 15 UNTS 295 (Chicago Convention).

${ }^{64}$ In essence, the Chicago system requires the approval of both states at each end of an international air route in relation to the airlines authorised to operate the route and the conditions under which they can do so, including frequency, capacity and fares. For a detailed description of the highly regulated Chicago Convention system, see Bin Cheng, The Law of International Air Transport (1962).

${ }^{65}$ Hussein Kassim, "Air Transport", in H. Kassim and A. Menon (eds.), The European Union and National Industrial Policy (1996) p. 111.

${ }^{66}$ Deregulation started a decade earlier in the US. In Europe, deregulation was related to the development of the single market in aviation, in particular the adoption of the so-called 'third package.' On air transport liberalisation in the EU, see Kenneth A. Armstrong and Simon Bulmer, The Governance of the Single European Market, (1998) pp. 169-197.

${ }^{67}$ Kassim, supra note 65, p. 126.

${ }^{68}$ René Van den Polder, "Lobbying for the European Airline Industry", in R. H. Pedler and M. P. C. M. Van Schendelen (eds.), Lobbying the European Union : Companies, Trade Associations and Issue Groups (1994) pp. 103-119.
} 
that the positions adopted by the Dutch government in meetings of the EU Council of Ministers largely reflected those of KLM. ${ }^{69}$

\subsubsection{The role of IATA}

The International Air Transport Association (IATA) defines its mission as representing, leading and serving the airline industry. ${ }^{70}$ In other words, IATA is a worldwide trade association for the airline industry. Its airline members, taken together, represent over $80 \%$ of total worldwide air traffic. ${ }^{71}$

Historically, however, IATA has been far more than a mere trade association. Under the system of regulation of international aviation set up under the Chicago Convention, states would negotiate in bilateral agreements which airlines would be allowed to operate which routes between the two states concerned, as well as capacity and frequencies on those routes. While fares to be practised on the route would be subject to state approval, the determination of these prices was left essentially to negotiations between airlines carried out in the context of IATA-organised "tariff conferences", with states rubber-stamping the outcome of these negotiations. In addition to this official role in price regulation, IATA also contributed in many ways to the adoption of common rules by its member airlines, such as, for instance, contractual terms between airlines and passengers, through recommendations issued to its member airlines. IATA was therefore deeply embedded in the regulatory system of international aviation. While the gradual liberalisation of air transport at international level, first in the US and later in other jurisdictions, notably the EU, has led to the disappearance of the system of IATA tariff conferences and therefore of the formal regulatory role of IATA in that context, IATA has remained a significant actor and a privileged interlocutor for states when considering changes to air transport regulation at international level. IATA participates regularly in the work of ICAO, which is the UN specialised agency dealing with civil aviation created by the Chicago Convention with the mission to serve as a global forum for states to develop policies and standards related to civil aviation.

The depth of involvement of the airline industry, through IATA, in the regulation of air carriers liability towards passenger is patent when one looks at the regulatory history leading up to the Montreal Convention

\subsubsection{Historical involvement of airlines in the regulation of air carriers' liability towards passengers}

It was noted above that the Warsaw Convention had been adopted in 1929 to protect the nascent commercial aviation industry by severely limiting the liability of airlines towards, in particular, passengers. That the Warsaw Convention should have survived over 70 years throughout the period of massive growth of air passenger transport is astonishing, given the vigorous condemnations of the Convention by many commentators as "heinous, absurd, archaic, outmoded and outrageous" 72 and

\footnotetext{
${ }^{69}$ Van der Polder's case study on computerized reservation systems (ibid, 113-118) is, in this respect particularly instructive: in this case study, we see a policy proposed by the Commission to ensure transparency and neutrality of computerised reservations systems used by travel agents to book flights being partly obstructed so as to protect the commercial interests of airlines in relation to code-sharing agreements with other airlines, particularly US airlines.

$70<$ www.iata.org/en/about/mission > accessed 10 January 2020.

$71<$ www.iata.org/en/about > accessed 10 January 2020.

72 Eloise Cotugno, "No Rescue in Sight for Warsaw Plaintiffs from Either Courts or Legislature - Montreal

Protocol 3 Drowns in Committee", 58 Journal of Air Law and Commerce (1993) p. 745.
} 
the strong position adopted by the main state player in the field, the US, arguing for reform and coming extremely close to denouncing the Convention. ${ }^{73}$

There were numerous attempts at overhauling the Warsaw Convention, which were mostly unsuccessful. ${ }^{74}$ Meaningful change, however, came not so much from formal amendments to the Convention but rather from voluntary agreements entered into by the airlines under pressure from the US and, to a lesser extent, a number of other states. In that sense, the real-world Warsaw liability regime was to a significant extent determined by the extent to which major air carriers were willing to accept new rules more protective of consumers. The first of these agreements was the Montreal Inter-carrier Agreement in 1966, which IATA encouraged member airlines to sign in return from an assurance from the US government that it would withdraw its notice of denunciation of the Warsaw Convention. Under this agreement, carriers agreed to apply a much more favourable compensation regime for passengers than that legally applicable under the Warsaw Convention. ${ }^{75}$ The next significant change to the legal regime applicable to air carrier liability was the so-called "Japanese initiative", under which international Japanese carriers unilaterally agreed to accept liability up to SDR 100,000 on the basis of strict liability and without limit on the basis of a rebuttable presumption of fault. IATA followed a few years later with an inter-carrier agreement (the 1996 IATA agreement), which most international airlines are signatories to, establishing a liability regime similar to the Japanese initiative. ${ }^{76}$

\footnotetext{
${ }^{73}$ It should be recognised, however, that the position of the US was not entirely devoid of ambiguities: while the US Congress generally argued in favour of greater consumer protection by removing limits to liability or at least raising them very substantially, the position of the US government and relevant regulatory agencies was more nuanced and more receptive to the airlines' arguments. For a detailed account by individuals closely involved with the negotiations from the US side of the period leading to the notice of denunciation of the Convention by the US and its last minute withdrawal, see Lowenfeld and Mendelsohn, supra note 22, pp. 497602.

${ }^{74}$ The Convention was successfully amended by the 1955 Hague Protocol (Protocol to Amend the Convention for the Unification of certain Rules relating to International Carriage by Air signed at Warsaw on 12 Oct 1929, The Hague, 1955, ICAO Doc 7632), which however only made rather modest changes to the Convention. A further two attempts led to an agreed text: the 1971 Guatemala City Protocol (Protocol to Amend the Convention for the Unification of Certain Rules Relating to International Carriage by Air, Warsaw, 1929, as Amended by the Protocol Done at The Hague, 1955, Guatemala City, 1971, ICAO Doc 8932) and the 1975 Montreal Additional Protocol No 3 (Additional Protocol No. 3 to Amend the Convention for the Unification of Certain Rules Relating to International Carriage by Air signed at Warsaw on 12 October 1929 as Amended by the Protocols done at The Hague on 28 September 1955 and at Guatemala City on 8 March 1971, Montreal, 1975, ICAO Doc 9147). Neither came into force for want of sufficient ratifications. Some other minor amendments of a mostly technical nature were however agreed in Montreal in 1975. For an overview of the evolution from Warsaw to Montreal, see Bin Cheng, "A New Era in the Law of International Carriage by Air: From Warsaw (1929) to Montreal (1999)", 53 International and Comparative Law Quarterly (2004) pp. 833859.

75 The two differences were that: (i) the limit on the liability of the carrier under the agreement in case of a passenger's death or injury was raised to USD 75000 instead of the limit of approximately USD 10000 under the Warsaw Convention (or USD 20000 under the Hague Protocol) and (ii) the airlines agreed to waive their right to rely on Article 20(1) of the Convention to rebut the presumption of fault, thereby changing the liability regime from one of rebuttable presumption of fault to one of irrebuttable strict liability, save for contributory negligence of the passenger.

${ }^{76}$ The agreement consists in fact of two related agreements: IATA Intercarrier Agreement on Passenger Liability (IIA), 31 October 1995 and Agreement on Measures to Implement the IATA Intercarrier Agreement (MIA), May 1996. The 1995 is an agreement of principle whereas the details of the airlines' commitments are
} 
What these initiatives show is that the airlines, whether individually or through IATA, were clearly key players in the definition of the rules applicable to air carrier liability to passengers. As Abeyratne put it, the airline industry 'took over' the management of the Warsaw system. ${ }^{77}$ This is not to say that they unilaterally and autonomously decided what those rules should be. Clearly, they acted in the context of the shadow of potential governmental action, especially in the US. Nonetheless, they were key actors and the main interlocutor of governments in deciding which rules were or were not acceptable in relation to air carrier liability to passengers. The system of regulation changed only to the extent that the airlines were willing to accept those changes.

Overall, therefore, it is clear that the voice of airlines can be heard loud and clear in processes of regulation at international level. By way of contrast, outside the sphere of domestic politics and legislative processes ${ }^{78}$ there is little room for passengers to be in a position to express their views in an influential manner. This imbalance in representation between airlines and passengers in international air transport regulatory processes is compounded by the natural tendency of international consumer rights protection to head towards lower echelons of protection.

\subsection{The tendency towards the lowest common denominator in international protection of consumer rights}

The case for harmonization of the rules on liability of air carriers towards passengers is rarely discussed. It seems to be generally accepted in the field as quasi-axiomatic that uniformity of rules on liability of carriers is in principle a good thing. If pushed, supporters of uniformity will usually argue that uniformity is desirable to regulate an activity that is inherently international, ${ }^{79}$ in particular to avoid potential problems arising out of conflicts of laws. ${ }^{80}$ Such generalisations are, however, debatable. The international nature of an activity should certainly lead us to reflect whether, and if so to what extent, the activity should be regulated at local, regional or international level. However, it cannot be taken for granted that the international level is a priori the more appropriate level of regulation. There is a danger here of adopting again an industry-centric view rather than a consumer-centric one.

From the perspective of the industry, there is a case to be made that, regardless of their substantive content, uniform rules per se facilitate cross-border trade. ${ }^{81}$ The argument here has two main dimensions: first, a company trading across multiple jurisdiction only has to familiarise itself with one set of uniform rules rather than a multiplicity of legal systems, each with its own vagaries and peculiarities. Thus, an airline providing air services from Frankfurt to Buenos Aires, Tokyo,

\footnotetext{
in the 1996 agreement. The text of both agreements can be found in Essential Documents on International Air Carrier Liability, 3rd edition (International Air Transport Association, 2012).

${ }^{77}$ Ruwantissa I. R. Abeyratne, "Regulatory management of the Warsaw System of air carrier liability", 3 Journal of Air Transport Management (1996) p. 38.

${ }^{78}$ Or the quasi-domestic processes of a supranational organisation like the EU.

${ }^{79}$ See George N. Tompkins, "Limitation of Liability by Treaty and Statute", 36 Journal of Air Law and Commerce (1970) pp. 432-433.

${ }^{80}$ Cheng, supra note 74, p. 834.

${ }^{81}$ Indeed, much work on harmonisation of private law, in particular contract law, tends to be based on this premise: see, inter alia, Ingeborg Schwenzer, "Global unification of contract law", 21 Uniform Law Review (2016) p. 60; Ewan McKendrick, "Harmonisation of European Contract Law: The State We Are In" in S. Vogenauer and S. Weatherill (eds.), The Harmonisation of European Contract Law, Implications for European Private Laws, Business and Legal Practice (2006), pp. 14-15; John Cartwright, "Harmonisation Projects: Lessons from the European Experience?", 2 Latin American Legal Studies (2018) pp. 165-167.
} 
Johannesburg or Toronto would not have to preoccupy itself with the intricacies of German, Argentinian, Japanese, South African or Canadian tort law with respect to its liability towards passengers nor with specific consumer legislation in these jurisdictions and could instead rely on the uniform international rules with respect to their liability towards all of their passengers, regardless of where they originate from or fly to. Secondly, uniform rules avoid the uncertainty, and potential opportunistic forum shopping, ${ }^{82}$ resulting from divergent private international law rules depending on the national jurisdiction where litigation is started. For airlines, therefore, the advantages of being regulated by uniform international rules, as long as those rules are not in themselves excessively onerous, is therefore clear. The same may also be true, albeit perhaps to a lesser degree, for many cargo consignors and consignees, especially for those who regularly ship or receive goods to or from multiple jurisdictions.

For passengers, however, the benefits of harmonisation are rather more debatable. There has been a growing tendency in private international law, especially, ${ }^{83}$ but not exclusively, ${ }^{84}$ in Europe, to recognise that international consumer transactions call for specific solutions compared to other commercial transactions and that expecting consumers to seek legal redress in foreign courts under foreign law is generally illusory and tantamount to depriving them of any realistic remedy. With respect to the question of applicable law, having uniform rules is one solution to this issue but it is not the only one. Another one, exemplified in the EU by Article 6 of the Rome I Regulation, ${ }^{85}$ is to ensure that consumers, at any rate 'passive' consumers who do not actively physically or virtually cross the border to seek goods and services from a supplier in another State, are not deprived of the protection afforded by mandatory consumer protection rules in their home state.

A major problem with relying on uniform rules versus local protection of the home state of the consumer lies in the difficulty of finding a universally acceptable standard for what constitutes an appropriate level of consumer protection. Consumer expectations tend to be closely bound to the socio-economic context of the place of residence of the consumer. Our understanding of what a

\footnotetext{
${ }^{82}$ This assumes that forum shopping is something to be avoided, which some might perhaps wish to question: see Pamela K. Bookman, "The unsung virtues of global forum shopping" 92 Notre Dame Law Review (2016) p. 579.

${ }^{83}$ With respect to consumers domiciled in the EU, Article 18 of the recast Brussels I Regulation (Regulation (EU) No 1215/2012 of the European Parliament and of the Council of 12 December 2012 on jurisdiction and the recognition and enforcement of judgments in civil and commercial matters [2012] OJ L351/1) and Article 6 of the Rome I Regulation (Regulation (EC) No 593/2008 of the European Parliament and of the Council of 17 June 2008 on the law applicable to contractual obligations [2008] OJ L6/109) provide that jurisdiction over consumer contracts falls to courts in the Member State where the consumer is domiciled and that mandatory consumer protection rules in the law of that Member State apply regardless of the law applicable to the contract.

${ }^{84}$ With respect to applicable law, see, in particular, the adoption by MERCOSUR on 21 December 2017 of a Convention on the Applicable Law to International Consumer Contracts, providing for the application of the law most favourable to the consumer (see Decision 36/17 of the Mercosur Common Market Council, available at https://normas.mercosur.int/simfiles/normativas/67229_DEC_036-

2017_ES_Acuerdo\%20Inter\%20Consumo.pdf (accessed 10 January 2020). With respect to jurisdiction and recognition of judgments rather than applicable law, see the special consideration given to consumer issues in a number of Hague Conventions, such as the exclusion of consumer contracts in Article 2(1) of the 2005 Hague Convention on Choice of Court Agreements or the special rules regarding consumer contracts Article 5(2) of the Hague Convention of 2 July 2019 on the Recognition and Enforcement of Foreign Judgments in Civil or Commercial Matters.

${ }^{85}$ See supra note 83 above.
} 
consumer can and should reasonably expect is anchored in our local legal culture. What is regarded as entirely appropriate protection of consumers in one society may well be regarded in another as unwarranted and costly paternalistic interference with economic freedom in another. We cannot assume that air passengers from Japan, Fiji, Denmark, China, Bolivia, Canada or Ethiopia all share a common perspective of what consumer protection legislation in air transport should achieve. The preamble of the Montreal Convention expresses the conviction of the parties that "collective State action for further harmonization [...] is the most adequate means of achieving an equitable balance of interests." However, the very notion that an "equitable balance of interests" is something that can be defined universally, outside any particular socio-economic context seems highly dubious. We may well be capable in the context of treaty negotiations to reach some kind of agreement but it does not follow from this that this agreement will be reflective of an "equitable balance of interests". In fact, it is more likely than not that this agreement will not reflect such a balance: an agreement seeking unified rules across a wide geographical scope is likely to tend towards the lowest common denominator so as to achieve the maximum number of ratifications across a large number of states. As Wilhemsson has pointed out, harmonisation of private law is not ideologically neutral: the development of rules of consumer protection or other 'welfarist' approaches tend to be closely-bound to social and cultural developments within states. Harmonisation of private law tends therefore to push towards a return to classical liberalism. ${ }^{86}$ The trend in European consumer law in the last ten years towards total harmonisation has not been without critics ${ }^{87}$ The case against total harmonisation is a fortiori considerably stronger at the broader international level, characterised by much greater diversity in terms of legal culture and consumer expectations as well as by a much less integrated, responsive and democratically accountable law-making system.

If, therefore, the adoption of uniform rules resolves some of the difficulties not only for airlines but also for passengers that result from the potential application of multiple legal systems to their legal relations, it does so at a potentially significant cost for passengers in jurisdictions with higher than average levels of consumer protection, who may lose the higher level of protection afforded by the local law. To that extent, uniform rules are a second-best solution over the compulsory application of mandatory consumer protection rules in the consumer's home state. ${ }^{88}$ Admittedly, application of local rules does represent additional complexity and costs to airlines. However, if a trader decides to enter the market of a given state by directing their commercial activities towards consumers in that state, it is reasonable that such a trader be subject to local regulatory standards, including those related to consumer protection.

\footnotetext{
${ }^{86}$ Thomas Wilhemsson, "Private Law in the EU - Harmonised or Fragmented Europeanisation?", 1 European Review of Private Law (2002) pp. 84-89.

${ }^{87}$ Reich has been particularly vocal in its criticisms of full harmonisation. See, inter alia, Hans-W. Micklitz and Norbert Reich, "Crónica de una muerte anunciada: The Commission Proposal for a 'Directive on Consumer Rights", 46 Common Market Law Review (2009) pp. 471-519.

88 It should be noted that rejecting uniformity does not necessarily mean rejecting global standards of liability. The question is not whether global rules are desirable or not but rather whether they should impose a uniform standard of liability, pre-empting local rules which provide for a higher standard of consumer protection. As will be discussed below in section 4.2, one may see a useful role for global rules that represent the minimum internationally acceptable level of liability of air carriers while recognising the possibility for local law to impose a higher standard.
} 


\subsection{Are consumer rights human rights?}

There has been a growing tendency in the last couple of decades to approach consumer rights in terms of fundamental rights. Writers such as Deutsch ${ }^{89}$ or Benöhr and Micklitz ${ }^{90}$ have thus argued in favour of recognizing consumer rights as belonging to a third generation of human rights. From a procedural point of view, they would point out the increasing degree of recognition of the importance of consumer protection in international instruments, such as the United Nations Guidelines on Consumer Protection (UNGCP), and the enhanced protection of consumer rights in national or regional constitutional documents. ${ }^{91}$ From a substantive point of view, they would draw attention to the increased need for consumer protection at international level resulting from globalisation and highlight the similarity between consumer rights and other economic and social rights as well as the existence of some rights which are already recognised as fundamental rights, ${ }^{92}$ some aspects of which could be seen as a particular manifestation of, or at least related to, consumer rights.

Aside from the age-old scepticism among some towards economic and social rights in general, ${ }^{93}$ objections to recognition as human rights of consumer rights specifically tends to follow one of two lines of argument.

The first line of argument links back to what we might call following Alston the 'quality control' issue: ${ }^{94}$ consumer rights would not be fundamental enough to deserve the 'human rights' label. The argument here is that fundamental rights inflation debases the fundamental rights currency and makes it less useful. If virtually every right is a successful candidate for the 'human' or 'fundamental' epithet, the concept of human rights or fundamental rights loses its distinctiveness. The invocation by advocates of consumer rights as human rights of recognition in instruments such as the UNGCP is to some extent an attempt at showing that this quality control threshold has been met. Opinions might differ as to whether this is the case and the fact that the UNGCP largely eschew the language of fundamental human rights does not help in this respect. Harding, Kohl and Salmon, however, approach this concern from a slightly different angle. ${ }^{95}$ They acknowledge the issue of potential risk of devaluation of the fundamental rights currency. To use their metaphor, if the 'fundamental right' label is meant to function as a trump card over ordinary, non-fundamental rights, it becomes useless if all the cards in the pack are trump cards. This, however, does not necessarily lead to rejecting new categories or types of fundamental rights. Such an approach could, they argue, be insufficiently

\footnotetext{
89 Sinai Deutsch, “Are Consumer Rights Human Rights?”, 32 Osgoode Hall Law Journal (1994) p. 537.

90 See Iris Benöhr and Hans-W. Micklitz, "Consumer protection and human rights", in G. Howells, I. Ramsay, T. Wilhemsson and D. Kraft, Handbook of Research on International Consumer Law (2010) pp. 18-46.

${ }^{91} \mathrm{See}$, for instance, the inclusion of an article on consumer protection (Article 38 ) in the EU Charter of Fundamental Rights.

${ }^{92}$ See, for instance, the discussion on the right to an adequate standard of living in Article 11 of the International Covenant on Economic, Social and Cultural Rights in Benöhr and Micklitz, supra note 90, p. 21.

${ }^{93} \mathrm{Cf}$ : "' $[$ E]conomic and social rights' cannot logically be considered universal human rights" in Maurice Cranston, What are Human Rights? (1973) p. 54.

${ }^{94}$ See Philip Alston, "Conjuring up New Human Rights: A Proposal for Quality Control", 78 American Journal of international Law (1984) p. 607.

${ }^{95}$ Christopher Harding, Uta Kohl and Naomi Salmon, Human Rights in the Market Place : The Exploitation of Rights Protection by Economic Actors (2008) pp. 95-96.
} 
sensitive to societal change. Another way to address the issue might be through the balancing of interests that is inherent in fundamental rights adjudication in all but a handful of exceptions. ${ }^{96}$ Recognising consumer rights as fundamental rights does not necessarily imply that every aspect of consumer protection should be regarded as capable of trumping any competing claim.

The second line of argument often invoked against recognition of consumer rights is that fundamental rights are rights against the State. Consumer rights are invoked in the market place for the most part against private parties, making them, the argument goes, unsuitable for recognition as fundamental rights. One could counter-object that, while it is indeed the case that pure 'horizontal' effect of fundamental rights between private parties is rather uncommon, ${ }^{97}$ it is nonetheless the case that 'indirect' or 'diagonal' application of fundamental rights norms, flowing from a duty on the State to protect individuals from interference with their fundamental rights by a private party, is generally accepted in human rights law. ${ }^{98}$

While there is therefore a plausible case for seeing consumer rights as fundamental rights, it might not even be necessary for consumer rights to share every single attribute of the concept of fundamental rights for our present purposes.

One of the attractions of a fundamental rights discourse in the consumer sphere is that it brings to the fore the underlying power structure that brings about inequalities and potential for abuse. Consumer law is premised on the existence of such an inequality between consumers and traders to the detriment of the former. Approached from a fundamental rights point of view, the function of consumer rights is to protect or empower the structurally weaker party in market transactions so as prevent exploitation and abuse of power by the other side.

This asymmetry between the parties and the notion of consumer law as designed to protect one side is what matter most for us here. One of the declared aims of the Montreal Convention, as affirmed in its preamble, is to achieve "an equitable balance of interests" between the parties. There are two ways, however, in which we can approach the question of balance of interests between the parties. We can adopt the commutative logic that underlies classical contract law, in which both parties to the contract are in principle interchangeable. Within that logic, we can, for instance, regulate international contracts for the sale of goods in a manner that achieves an 'equitable balance of interests' between buyer and seller. In the context of the Montreal Convention, it might perhaps be appropriate for the provisions of the Convention relating to the carriage of cargo to achieve an 'equitable balance' between the interests of consignor, consignee and carrier.

If, however, we regard passengers as consumers and consumer rights as fundamental rights, a different approach is required. The objective of achieving an 'equitable balance of interests' remains.

\footnotetext{
96 Protection from torture would spring to mind as one such exception.

97 The case of horizontal application of constitutional rights in South Africa and, to a lesser extent, Ireland are often discussed as exceptions to the general situation. For a discussion of horizontal application of social and economic rights in these two jurisdictions, see Aoife Nolan, "Holding non-state actors to account for constitutional economic and social rights violations: Experiences and lessons from South Africa and Ireland", 12 International Journal of Constitutional Law (2014) pp. 61-93.

${ }^{98}$ For a discussion of the issue in the context of the European Convention on Human Rights, see Andrew Clapham, Human rights in the private sphere (1993). More generally, see Jan Arno Hessbruegge, "Human Rights Violations Arising from Conduct of Non-State Actors", 11 Buffalo Human Rights Law Review (2005) pp. 21-88.
} 
As noted above, ${ }^{99}$ most fundamental rights adjudication involves a balancing of interests. However, achieving that balance has to recognise the asymmetry between the parties. Achieving such a balance in this context is essentially an exercise in redressing the imbalance in power between them.

\subsection{Protecting consumer rights at international level: the relevance of human rights}

We saw above that consumer expectations tend to be closely bound to the socio-economic context in which the consumer lives, which makes the case for unification of consumer law at international level rather difficult to defend. This does not mean, however, that there is no role for consumer law at the international level and human rights law provides a useful point of reference in this respect.

While the very idea of 'human' rights contains an implicit aspiration to universality, it must at the same time recognise that those rights are exercised in a wide variety of cultural and socio-economic environments which may call for a certain degree of adaptation or accommodation to different national legal contexts. The notion of subsidiarity can be used as a broad conceptual umbrella to encompass the various tools and techniques developed by human rights law at international, regional and local level to attempt to resolve that tension between universalism and localised differentiation. ${ }^{100}$

It is not the place here to go into the details of those tools and techniques, many of which may be of limited direct relevance for our present concerns, nor should we regard subsidiarity as a panacea with the ability to unequivocally settle debates about the respective roles of international, supranational or national law in protecting rights. As Føllesdal observed, what subsidiarity does is to help us structure, rather than resolve, debates about allocation of authority in a multilevel system. ${ }^{101}$ However, the idea of coordination and complementarity between various levels of regulation, which subsidiarity carries with it, provides us with a useful way to look at the role of consumer law at the international level. To the extent that we are talking about protecting rights, provisions like Article 53 of the European Convention on Human Rights ${ }^{102}$ or Article 53 of the EU Charter of Fundamental Rights, ${ }^{103}$ which seek to preserve the protection afforded by other instruments, contribute to the development of a multi-layered system of rights protection in which each level acts as floor on which more localised levels might build further.

Thus, whether one fully accepts consumer rights as human rights or not, this notion of a multi-level system of rights protection in which the complementary roles of various layers are recognised seems attractive. It is difficult to see, however, how such an approach can be reconciled with the logic of

\footnotetext{
${ }^{99}$ Supra note 96.

100 See Paolo G. Carozza, "Subsidiarity as a Structural Principle of International Human Rights Law", 97 American Journal of International Law (2003) pp. 38-79.

${ }^{101}$ Andreas Føllesdal, "Subsidiarity and International Human-Rights Courts: Respecting Self-Governance and Protecting Human Rights - or Neither", 79 Law and Contemporary Problems (2016) p. 163.

${ }^{102}$ Article 53 ECHR provides that "[n]othing in this Convention shall be construed as limiting or derogating from any of the human rights and fundamental freedoms which may be ensured under the laws of any High Contracting Party or under any other agreement to which it is a Party."

${ }^{103}$ Article 53 of the Charter provides that "[n]othing in this Charter shall be interpreted as restricting or adversely affecting human rights and fundamental freedoms as recognised, in their respective fields of application, by Union law and international law and by international agreements to which the Union, the Community or all the Member States are party, including the European Convention for the Protection of Human Rights and Fundamental Freedoms, and by the Member States' constitutions."
} 
unification of rules and complete isolation from other norms that underlies Article 29 of the Montreal Convention.

\subsection{Subsidiarity and the Montreal Convention}

Subsidiarity and exclusive jurisdiction are antithetical. Adopting a subsidiarity-oriented reading of the Montreal Convention would therefore require us to minimize the effect of Article 29.

At a maximalist end of the spectrum, one can read the exclusivity clause in the Montreal Convention as excluding any liability or carrier towards passengers other than under the Convention while passengers are on board or embarking or disembarking from the aircraft. This was the path chosen by the US Supreme Court in Tseng ${ }^{104}$ and the UK House of Lords in Sidhu ${ }^{105}$ in the context of Article 24 of the Warsaw Convention.

At the minimalist end, one could read the exclusivity of the Montreal Convention as being limited to cases involving liability for death or physical injury resulting from an accident on board or during embarkation and disembarkation and not covering situations which do not constitute an accident or liability claims for other damage than death or physical injury. Limiting the exclusivity to liability resulting from accidents would lead to a different outcome not only in cases like Tseng or Sidhu but also in cases like King, Thibodeau or Stott ${ }^{106}$ where the liability is anchored in public law and constitutional norms.

Whether the maximalist interpretation adopted in Tseng and Sidhu was justified is debatable. McDonald has convincingly argued that such a wide interpretation could not be seen as straightforwardly flowing from either the wording or purpose of the Warsaw Convention and that there are strong arguments for adopting a narrower reading of the exclusivity clause. ${ }^{107}$ Regardless of what constituted the proper interpretation of the Warsaw Convention, the fact that the Montreal Convention attempts to shift the cursor to some extent in the direction of the consumer and explicitly refers to consumer protection in the preamble could constitute an argument in favour of a less extensive reading of its Article 29, notwithstanding the absence of significant material change in its wording compared to Article 24 of the Warsaw Convention. The sensitivity of consumer issues to the socio-economic context would also militate in favour of an evolutive reading of norms affecting consumer rights similar to what is practised in the context of human rights, such as the living instrument' approach to the ECHR of the European Court of Human Rights. ${ }^{108}$ The precedent of being trapped for seventy years with the Warsaw Convention in a legal regime which had for decades been recognized as anachronistic provides us with a clear example of why such an evolutive approach is required in consumer matters. The process of amending multilateral treaties is too slow and cumbersome to allow for a nimble, flexible and reactive adaptation to constantly changing socio-economic environments and market circumstances.

\footnotetext{
104 Supra note 24.

105 Supra note 25.

106 Supra notes 37,31 and 35 respectively.

107 Supra note n23, pp. 213-215 and 224-229.

${ }^{108}$ For a recent discussion of the appropriateness of this approach, see Stefan Theil, "Is the 'Living Instrument' Approach of the European Court of Human Rights Compatible with the ECHR and International Law?", 23 European Public Law (2017) pp. 587-614.
} 
If we turn to state practice since the adoption of the Montreal Convention, it would tend to suggest that the parties' understanding of the scope of their obligations under the Convention is not quite in line with a maximalist interpretation of Article 29. It is not just the European Union ${ }^{109}$ with Regulation $261 / 2004^{110}$ but also numerous other states ${ }^{111}$ which have felt the need to adopt additional legislation to assist consumers in case of flight delays and cancellations to provide protection going further than the Convention.

The industry, in particular through IATA, has been strongly opposed to these initiatives, expressing concern before the European Court of Justice ${ }^{112}$ and elsewhere ${ }^{113}$ that they ran counter to the exclusivity of the Montreal Convention. We noted above that the European Court of Justice had taken a different view and considered the EU legislation compatible with the Convention and an alternative explanation was also put forward to defend the view that air passenger rights legislation similar to Regulation 261/2004 should fall outside the scope of Article 29 of the Convention. ${ }^{114}$ The fact that no less than around half of the signatories to the Montreal Convention have adopted such legislation would seem consistent with the view that the states themselves have a rather different and more minimalist and consumer-friendly reading of Article 29 than IATA.

\section{Conclusion}

The aim of elaborating a universally applicable system of liability of air carriers towards passengers in the Montreal Convention comes at a substantial price in terms of consumer protection. As currently interpreted by the industry, the majority of aviation law scholars as well as cases such as Tseng, Sidhu or Stott, ${ }^{115}$ the exclusivity of the Montreal Convention has the effect of enveloping airlines in a protective shield where, as long as no accident, death or injury ensues, passengers who step onboard an international flight are largely stripped of many rights that they would take for granted on the ground.

109 The example of the European Union has, however, been influential, leading Havel and Mulligan to speak of the 'norm entrepreneurship' of the EU in this domain: Brian F. Havel and John Q. Mulligan, "Extra-territorial Application: Exporting European Consumer Protection Standards' in M. Bobek and J. Prassl (eds.), supra note 2, p. 251. Jurisdictions whose legislation appear particularly influenced by EU rules include Brazil, India, Nigeria, Israel, Turkey and the Philippines. For other jurisdictions having comparable For examples of other states with broadly comparable air passenger protection legislation, see Vincent Correia and Noura Rouissi, "Global, Regional and National Air Passenger Rights - Does the Patchwork Work?" 40 Air and Space Law (2015) pp. 123146.

110 Supra note 38.

${ }^{111}$ As of August 2018, ICAO's secretariat had identified no less than 60 states which had adopted aviationspecific consumer protection regulations, viz. almost half the number of signatories of the Montreal Convention: ICAO Working Paper on Assistance to Passengers in case of airport/airline disruption, C-WP/14804 of 23/8/18, Revision I (13/9/18), www.icao.int/sustainability/Documents/C.215.WP.14804.REV1.EN.PDF (accessed 10 January 2020). ICAO maintains a database of consumer protection rules applicable to passenger air transport at wwwicao.int/sustainability/Pages/ConsumerProtectionRules.aspx (accessed 10 January 2020). 112 See the IATA case, supra note 7.

${ }^{113} \mathrm{See}$, in particular, the concern that "national and regional legislation should be consistent" with the Warsaw and Montreal Conventions expressed in the Resolution on Core Principle on Consumer Protection adopted at the 69th IATA Annual General Meeting, Capetown, June 2013, www.iata.org/contentassets/771d2065c8914f80b1adc8a06bdb59ed/agm69-resolution-passenger-rights.pdf (accessed 10 January 2020).

${ }^{114}$ See the discussion of the IATA case earlier in this article.

115 Supra notes 24, 25 and 35 respectively. 
The unification of (certain) rules is an explicit objective of the Convention. It is therefore unavoidable that the Convention will have the effect of insulating airlines from the consequences of liability that might otherwise arise under national or supranational law. The question is the extent of the immunity it bestows on carriers. If one looks at the Montreal Convention as primarily a trade facilitation instrument, the function of which is to protect airlines from the vagaries of national and supranational liability rules, be it at the detriment of consumers, it makes perfect sense to give the Convention the maximum pre-emptive effect over national and supranational law. This was clearly the case of the 1929 Warsaw Convention, whose purpose was unambiguously to severely limit the liability of airlines. If, however, one considers that the main object of the Montreal Convention is to protect consumers rather than facilitating trade and protecting airlines, a more restrictive interpretation of the scope of pre-emption by the Convention is in order.

One cannot count on regulation of airline liability towards passengers at international level to be sufficiently protective of consumers. This is partly due to the international legal environment being more open to influence from industry than consumers. The air transport industry provides a particularly striking example of this with the deep embedding of industry interests in the international regulatory environment, notably through IATA. More fundamentally, however, even if a more balanced representation of interests could be achieved, the problem remains that the weight that should be given to consumer interests and the form that consumer protection should take tends to be closely bound to the particular socio-economic context in which it arises. Uniformity might make sense in a relatively homogeneous group of states where expectations are broadly comparable. At a universal level, however, conceptions of consumer protection are too heterogeneous to allow for a uniform approach.

This paper has put forward the view that a human rights-inspired approach to the protection of consumer interests, and in our particular context air passenger rights, centred on the idea of subsidiarity is required if we are to treat air passenger rights seriously. Ultimately, this should lead us to completely reject the pre-emptive effect of the Montreal Convention and approach the Convention as offering a floor of protection to which national and supranational law can add. This would require the Convention to be amended. Even without amendment, however, it should be possible, as was argued above, to adopt a more consumer-friendly, evolutive and subsidiarityoriented of the Convention so as to at least limit its pre-emptive effect and adapt it to the evolution of our expectations in terms of consumer protection. Is it really defensible in an era that recognises consumer rights to adopt an interpretation of the Montreal Convention which would leave a consumer who has purchased an expensive airline ticket without legal recourse against an airline which denies her any of the on board amenities that are associated with such a ticket ${ }^{116}$ Is it really defensible to adopt an interpretation of the Montreal Convention which would leave an individual who has been deliberately discriminated on the basis of their race or a disabled passenger who has been treated in an inhumane or degrading manner without legal recourse against the airline responsible for such acts? ${ }^{117}$ This writer thinks not.

\footnotetext{
116 See supra note 30.

${ }^{117}$ Cf King (supra note 37) and Stott (supra note 35).
} 